
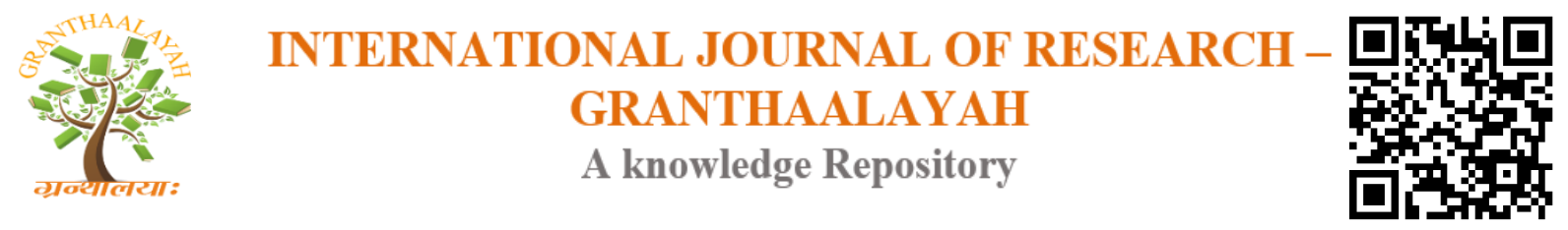

Management

\title{
IDENTIFICATION OF POTENTIALS AND COMMUNITY PERCEPTIONS IN TOURISM VILLAGE PLANNING BASED ON POTENTIAL RESOURCES OF VILLAGE
}

\author{
IB Wisnu Mahendra ${ }^{1}$, I Ketut Sumantra ${ }^{1}$, I Ketut Widnyana*1, Nyoman Utari Vipriyanti ${ }^{1}$ \\ ${ }^{1}$ Graduate Program in Regional Development Planning and Environmental Management, \\ Mahasaraswati Denpasar University, Denpasar-Bali, Indonesia
}

\begin{abstract}
Tabanan Regency in Bali has many villages that have tourism potential but have not developed yet, one of them is Munduk Temu village located in Pupuan District. This study aims to identify the tourism potential of the village and to determine people's perceptions in the development of rural tourism. This research is descriptive qualitative, with data collection methods through direct surveys, and the distribution of questionnaires. The results showed that there are many tourism potentials in the village including: waterfall, hot spring baths, clear river water, salak and coffee plantations. Leading potential of the village is coffee plantations managed by the community with about $60 \%$ of the total area of the village. Public perception shows that the community agrees that the village of Munduk Temu has the potential to become a tourism village, but tourism accessibility is inadequate, tourism facilities are still limited, institutions are not yet available, but community awareness has grown, the community hopes to manage the tourism village independently, and urgently needs promotion media. It can be concluded that the village of Munduk Temu has the potential to be developed into a tourist village, but needs to be improved in various fields and promotions.
\end{abstract}

Keywords: Tourism Village; Identification; Perception; Coffee Plantation.

Cite This Article: IB Wisnu Mahendra, I Ketut Sumantra, I Ketut Widnyana, and Nyoman Utari Vipriyanti. (2020). "IDENTIFICATION OF POTENTIALS AND COMMUNITY PERCEPTIONS IN TOURISM VILLAGE PLANNING BASED ON POTENTIAL RESOURCES OF VILLAGE." International Journal of Research - Granthaalayah, 8(4), 13-22. https://doi.org/10.29121/granthaalayah.v8.i4.2020.3.

\section{Introduction}

Indonesia as an archipelago has natural potential that can be developed as an attraction for tourism. One of them is agriculture and plantation-based tourism. (Budiarjono and Wardiningsih 2013). One of the islands in Indonesia is Bali. Bali is an island that has many developed and undeveloped tourist areas. Bali Island is located in the middle of the entire islands in Indonesia, has an area of 
$5,633 \mathrm{KM}^{2}$ and a total population of around 4 million inhabitants (Central Statistics Agency of Bali Province, 2010).

The Balinese are largely dependent on agriculture and tourism. The development of Bali tourism has had a real influence on the economy of Bali. In a review of the Consultant Project Management and Comprehensive Tourism Development Plan for Bali which concluded that tourism has been a driving force for the development of Bali in these two decades. It was further said that the tourism sector will remain a leading sector in the economic development of Bali in the future. As a generator driving the development of the tourism sector can play the role of the Multiplier effect, namely tourism can move other sectors such as; the plantation sector, animal husbandry, the clothing industry, the handicraft industry, and various service sectors (Erawan, 1993).

The development and development of tourism that has been carried out should be able to be sustainable and be maintained in the future. In sustainable tourism, the emphasis on sustainability is not even enough just ecologically sustainable and sustainable economic development, but no less important is the sustainability of culture, because culture is one of the most important resources in tourism development. The implementation of these concepts is applied in the rural tourism development program, so that the development of tourism villages must be able to preserve the environment. Besides the strategies and programs produced can contribute to the economy of the community, improve their standard of living, so that the community will try to maintain the sustainability of tourism (Pitana, 2002). Village tourism is a form of integration between attractions, accommodation, and supporting facilities that are presented in a structure of community life that integrates with applicable procedures and traditions (Nuryanti, 1993).

Tabanan Regency is located about $35 \mathrm{Km}$ to the west of Denpasar City, bordered by Buleleng Regency to the north, Jembrana Regency to the embers, Badung Regency to the east, and the Indonesian Ocean to the south. Tabanan Regency has an area of $839.33 \mathrm{Km}^{2}$ (Central Statistics Agency of Tabanan Regency, 2019). Munduk Temu Village is one of the villages located in the western area of Tabanan Regency, namely in the District of Pupuan. Munduk Temu village has been established as a tourist village through the Tabanan Regent Decree Number: 180/314 / 03/2018. Munduk Temu Village is also part of the Nikosake Area which means Salak and Coconut Coffee Nira, which consists of 5 (five) villages namely Wanagiri, Belimbing, Sanda, Munduk Temu and Lumbung Kauh Districts through the Decree of the Tabanan Regent Number: 180/178/02 / HK \& HAM / 2018 has been established as an Integrated Agricultural Development Zone based on Tourism and local wisdom which is often referred to as agritourism.

Agritourism is an agribusiness activity where local farmers offer their farming and allow visitors to watch the maintenance of the garden, plant growth, harvesting, and processing of local food that appeals to local wisdom (Maruti, 2009). Wolfe and Bullen (2011) define agritourism as an activity, business or business that combines the main elements and characteristics of agriculture and tourism and provides an experience to visitors that encourages economic activity and impacts on farming and community income.

Potential areas of the village of Munduk Temu in Tabanan regency are mostly in the form of plantation land that has not been cultivated to the full. In addition to plantations, there are many other potentials that are worth developing to become a tourist destination. To develop tourism 
objects in the village of Munduk Temu, a plan that is able to raise the existing potential is needed. This study aims to identify the potential contained in the village of Munduk Temu and to determine people's perceptions in the development of rural tourism.

\section{Materials and Methods}

Study was conducted in Munduk Temu Village, Pupuan Subdistrict, Tabanan Regency which has an area of 1,542 ha, the research began in August 2019 until December 2019. This research is a qualitative descriptive study using the method of observation and questionnaire distribution. Observation method is carried out to determine the potential function of the area / environment; Economic / social / cultural potential; The physical condition of the area in the form of village infrastructure and facilities. Questionnaires were distributed to determine the community's response to the agritourism development plan. Questionnaires were distributed to 30 people in Munduk Temu Village and were randomly assigned.

\section{Results and Discussion}

\subsection{Potential Demographic Areas}

\section{The Potential Areas}

width of the Munduk Temu area is $1,542 \mathrm{Ha}$, with land use covering residential land covering 85 ha $(5.00 \%)$, public facility land covering 42.59 ha $(3 \%)$, plantation land covering $1,384.21$ ha $(90.00 \%)$, forest land 30 ha $(2.00 \%)$. Whereas paddy fields and wetlands are not available or as wide as 0 Ha. Table and land use chart of Munduk Temu Village can be seen in the following Table 1.

Table 1: Land use in Munduk Temu village area

\begin{tabular}{|l|l|c|c|}
\hline No & Land Use & Area (Ha) & Percentage \\
\hline 1 & Settlement Land & 85 & $5 \%$ \\
\hline 2 & Land Public Facilities & 42.79 & $3 \%$ \\
\hline 3 & Plantation land & $1,384.21$ & $90 \%$ \\
\hline 4 & Forest land & 30 & $2 \%$ \\
\hline 5 & Rice field & 0 & $0 \%$ \\
\hline \multicolumn{2}{|l|}{ Total } & 1,542 & $100 \%$ \\
\hline
\end{tabular}

Source: Prodeskel Profile of Munduk Temu Village, 2018

Based on land use conditions in Munduk Temu Village, it shows that most of the land in the Munduk Temu village area is $90 \%$ or $1,384.21 \mathrm{Ha}$ used for plantation land. The rest is used for settlements, public facilities and forests. There is no wetland and wetland in Munduk Temu which characterizes conditions that are different from other villages in Tabanan Regency, which is dubbed the Bali food barn, which relies on rice farming. In terms of land use, the potential of Munduk Temu Village is in the plantation sector, so that this sector has become a leading sector that has the potential to be developed in order to improve the welfare of the Munduk Temu Villagers. However, in the processing of the leading sector, it still faces constraints due to the limitations of human resources, facilities and infrastructure in processing, market certainty, and the low quality produced so that it has not been able to compete in the field. 


\section{Potential Population}

number of residents of Munduk Temu Village in 2016 was 3,834 people with the number of men totaling 1,896 people (49.45\%), women totaling 1,938 people $(50.55 \%)$. with 1,130 households spread across 6 (six) Banjar Dinas. Noting the data of the last 3 (three) years with the assumption of a population growth rate of 1.01 percent / year, the total population of Munduk Temu Village until 2018 amounted to 3,897 people, with a population density of 252 people / ha, and the productive age did not develop for 3 ( three) a total of 2,419 people. The population of Munduk Temu from 2016 until 2018 are as follows Table 2.

Table 2: Population in Munduk Temu village

\begin{tabular}{|l|l|c|c|c|}
\hline \multirow{2}{*}{ No. } & Description & \multicolumn{3}{|c|}{ Population in years } \\
\cline { 3 - 5 } & & $\mathbf{2 0 1 6}$ & $\mathbf{2 0 1 7}$ & $\mathbf{2 0 1 8}$ \\
\hline $\mathbf{1}$ & Total Population (People) & 3,834 & 3,832 & 3,897 \\
\hline $\mathbf{2}$ & Number of households & 1,130 & 1,130 & 1,156 \\
\hline $\mathbf{3}$ & Density (people / Km2) & 248 & 248 & 252 \\
\hline $\mathbf{4}$ & Productive Age (people) & 2,419 & 2,419 & 2,461 \\
\hline $\mathbf{5}$ & Non-Productive Age (people) & 1,415 & 1,413 & 1,436 \\
\hline $\mathbf{6}$ & Work Force (people) & & 2,995 & 3,181 \\
\hline
\end{tabular}

Source: Prodeskel Profile of Munduk Temu Village, 2018

Seeing the population density of Munduk Temu Village 252 people / km2, Munduk Temu Village is classified as rural with low density. Of the total population with a male population of 1,896 $(49.45 \%), 1,938$ women $(50.55 \%)$, with a ratio of $98.58 \%$, means that every 100 female population in Munduk Temu Village, there are 98 male residents. With a larger female population, this has an impact on the number of women of childbearing age, so that in the future programs and activities that are intended for women of childbearing age are needed such as reproductive health, as well as population control programs.

\section{Agricultural Potential}

Noting that the population of Munduk Temu Village is mostly farmers as farmers, and their land use is dominated by plantations, the plantation sector is the leading sector of Munduk Temu Village to be developed. The superior production from the plantation sector is coffee, salak, mangosteen, coconut, durian, cloves, roomie, and cocoa. From some of the superior plantations produced in the village of Munduk Temu are dominated by coffee with a planting area of $727.3 \mathrm{Ha}$, and a production of 3,178.4 Quintals / year, and the type of plant that is the least developed is the sap with a planting area of $1.50 \mathrm{Ha}$, with a production of 3.4 quintals, see Table 3.

Table 3: Plant types, number of trees, planted area and agricultural production in Munduk Temu village

\begin{tabular}{|l|l|c|c|c|}
\hline No. & Plant Types & Number of Trees & Planting Area & Production \\
\hline 1 & Coffee & - & $727.3 \mathrm{Ha}$ & 317.84 tons \\
\hline 2 & Salak & 2505 tree & - & 15.1 tons \\
\hline 3 & Mangosteen & 394.7 tree & - & 78.9 tons \\
\hline 4 & Coconut & - & $138.8 \mathrm{Ha}$ & $1.216,2$ tons \\
\hline 5 & Durian & 2,077 tree & - & 41.5 tons \\
\hline 6 & Cloves & - & $90 \mathrm{Ha}$ & 3.42 tons \\
\hline
\end{tabular}




\begin{tabular}{|l|l|c|c|c|}
\hline 7 & Nira & - & $1.50 \mathrm{Ha}$ & 0.34 tons \\
\hline 8 & Cocoa & - & $107.97 \mathrm{Ha}$ & 60.57 tons \\
\hline
\end{tabular}

Source: Prodeskel Profile of Munduk Temu Village, 2018

\subsection{Natural Potential}

\section{Waterfalls and Hot Springs}

Singsing Yeh Bau waterfalls are located in Munduk Temu Kelod Hamlet which is +/- 3 km from the main access road of the Seleksek-Kebonjero district, which passes through the resident's coffee plantations. This waterfall is unique because five springs become one in the waterfall with a height of 15-20 meters (Figure 1).
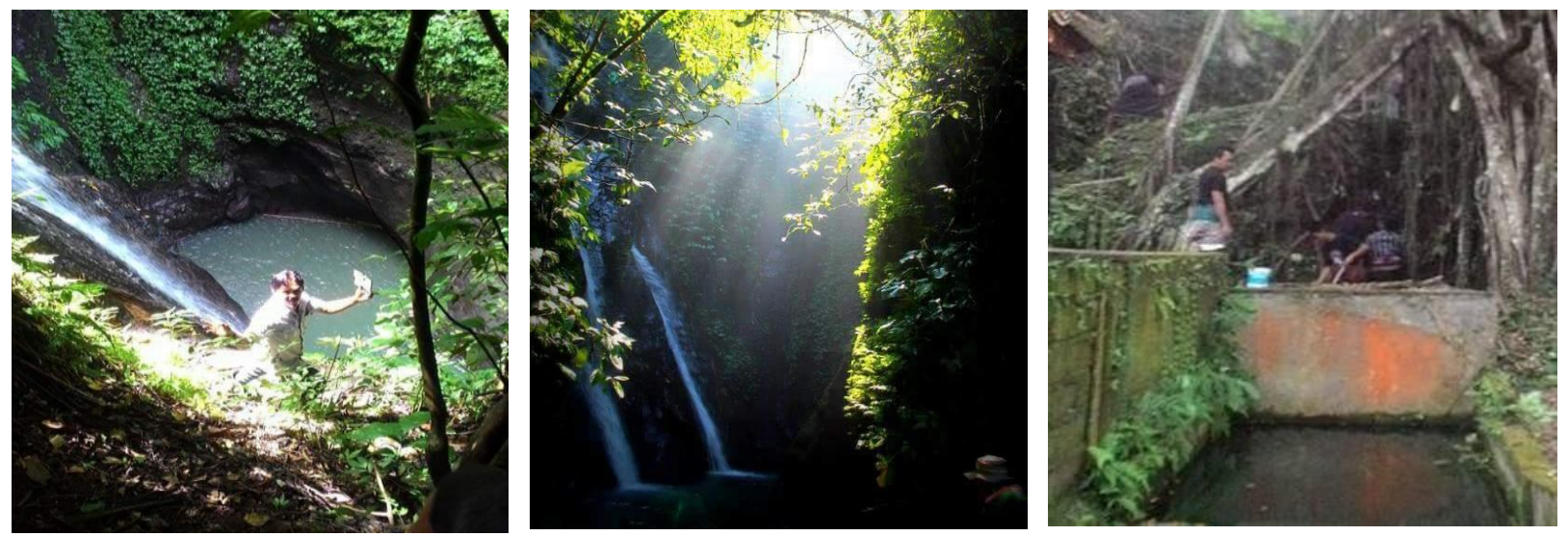

Figure 1: The existence of Singsing Yeh Bau waterfalls (left and center) and hot spring bath (right) in the village of Munduk Tabanan, Bali.

To support the waterfall's tourism activities, supporting facilities such as access road to the waterfall are still in the form of footpaths and potential arrangement tourist attraction as a tourist attraction in the Munduk Temu Tourism Village. The Banjasari Anggasari hot spring is located on the edge of the Yeh Hoo River which is the border river between Munduk Temu Village and Kebon Padangan Village. This hot water is located on the people's land and is still natural, but has often been used by residents for public baths. Hot water tourism still needs to be developed where the access road is still in the form of footpaths, as well as hot water areas that have not been arranged.

\section{Coffee and Salak Plantation in}

Munduk Temu Village, located at an altitude of 600 - 700 asl, with a bumpy topography, flanked by valleys, with cool temperatures, this is like a country above the clouds. With a vast expanse of coffee and zalacca plantations, supported by socio-cultural and customs life combined with superior agricultural sector production, with community empowerment to increase community economic growth, and combined with socio-cultural life that is still very thick, becomes the potential of Munduk Village Meeting to develop the economy of the local community through the development of a Tourism Village (Figure 2). 

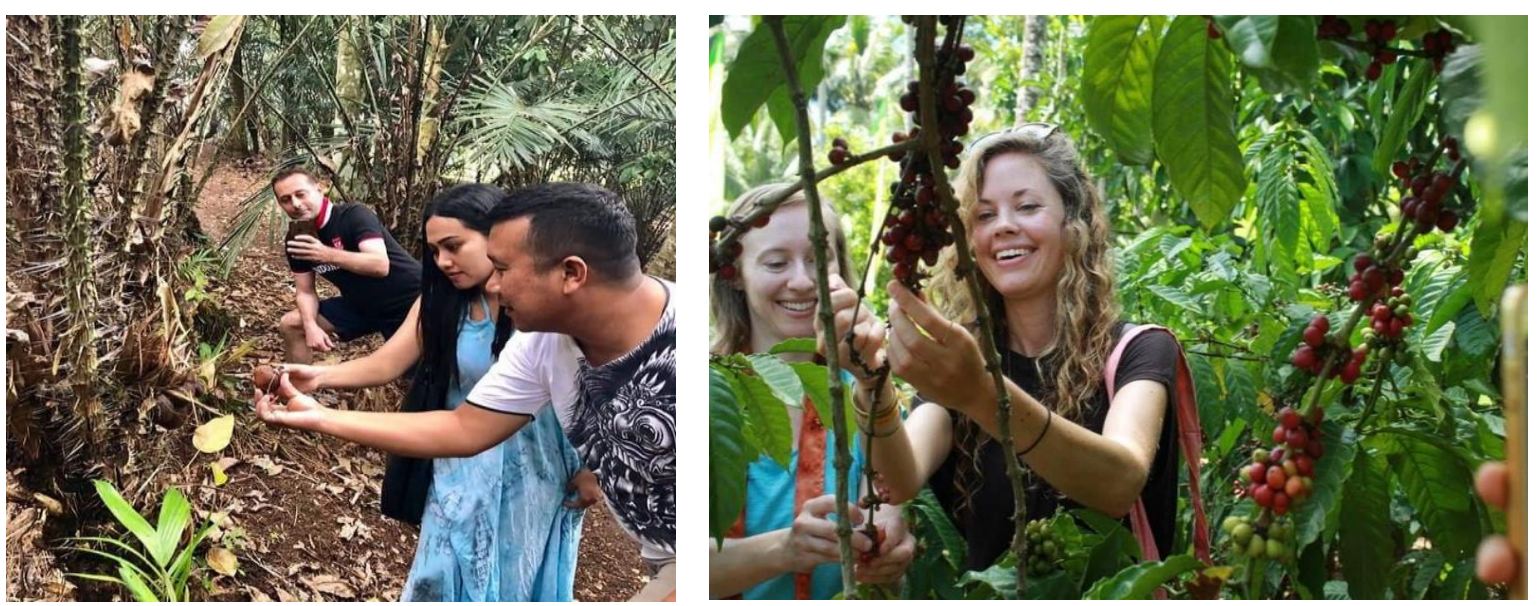

Figure 2: Potential of salak and coffee plantations in the village of Munduk Temu Bali

\section{Potential River with Clear Water}

Munduk Temu Village also has the potential to develop its water tourism, because Munduk Temu Village has a river that is wide enough with water that never recedes. Currently this water tourism is still used by village children to play, but it does not rule out the possibility of being developed as a tourist attraction to attract tourists (Figure 3)
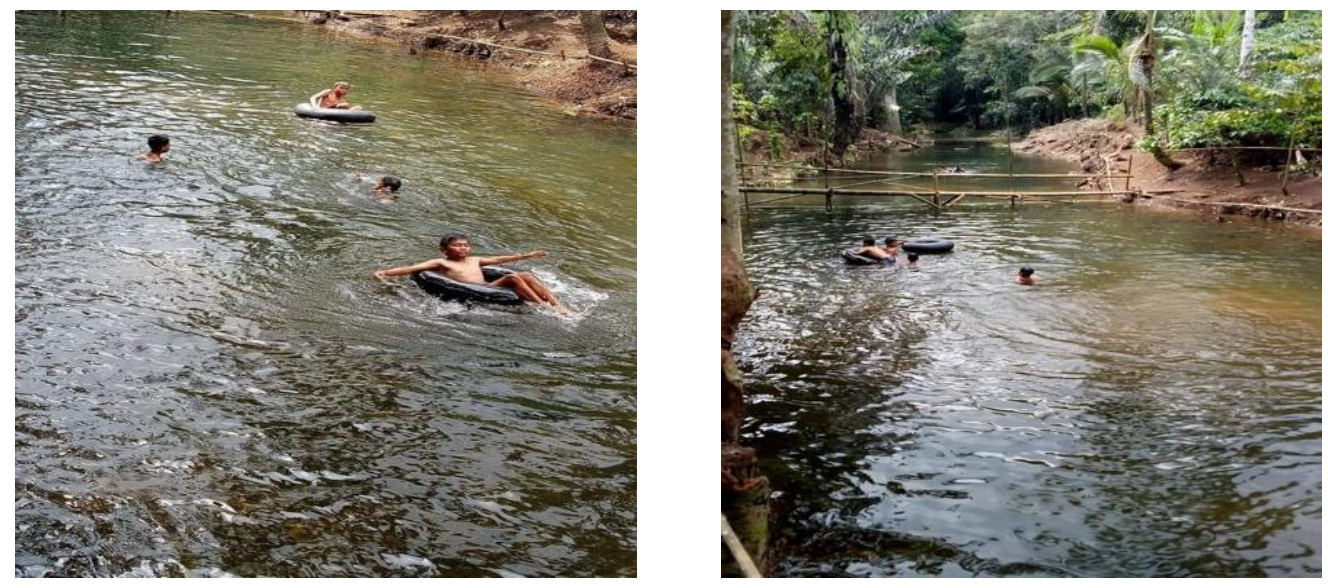

Figure 3: clear river water in the village of Munduk Temu Tabanan Bali

Munduk Temu Village is located in the hills and surrounded by cliffs, so it has a very good view. Munduk Temu village began to come up with an idea to make interesting and beautiful places as a place for photos for visitors. In addition to the potentials above that can be developed as a tourist attraction or tourist attraction that attracts tourists to visit Munduk Temu Village, there are also activities that are very interesting for tourists, especially foreign tourists to visit, namely farmers' activities that may be followed by tourists, such as harvest coffee in the harvest season and also participate in or study coffee processing.

\subsection{Community Response}

Results for distributing the questionnaire aimed to determine the response of the people obtained the public perception of a tourist attraction in the Village of Temu Munduk presented in Table 4. 
Table 4: Public perception of potential tourist attraction Munduk Temu village

\begin{tabular}{|c|l|c|c|c|}
\hline \multicolumn{2}{|l|}{ Component Fascination } & \multicolumn{3}{l|}{ Amount (\%) } \\
\cline { 3 - 5 } \multicolumn{2}{|l|}{} & Disagree & Doubt & Agree \\
\hline 1 & Having potential to be developed & - & - & 100 \\
\hline 2 & Utilization is still limited to local community use & - & - & 100 \\
\hline 3 & Potential attractiveness has begun to be managed & - & 3 & 97 \\
\hline 4 & Emerging trading activities around tourist attraction & - & 3 & 97 \\
\hline 5 & Emerging appeal from local activities & - & 3 & 97 \\
\hline 6 & Tourist attractions have expanded & - & 94 & 6 \\
\hline
\end{tabular}

The data in Table 4 shows that $100 \%$ of the community agreed that Munduk Temu Village had the potential to be developed into a tourism village, and also $100 \%$ agreed that the potential was still limited to use by the local community. Whereas for the potential that has been managed there are $3 \%$ who are still in doubt, $3 \%$ are in doubt with the existence of trading activities around the tourist attractions and the tourist attraction of the local culture. And as for the growing appeal, only $6 \%$ agree. Communities also $100 \%$ agree if there are trading activities around tourist attractions

Table 5: Community perception of village tourism accessibility Munduk Temu

\begin{tabular}{|c|c|c|c|c|}
\hline \multirow{2}{*}{\multicolumn{2}{|c|}{$\begin{array}{l}\text { Component } \\
\text { Accessibility }\end{array}$}} & \multicolumn{3}{|c|}{ Amount (\%) } \\
\hline & & Disagree & Doubt & Agree \\
\hline 1 & Development of tourism accessibility is still limited & - & - & 30 \\
\hline 2 & Access to the area is still in the form of public transportation & - & 3 & 97 \\
\hline 3 & There are no signposts for the existence of a tourist village & - & - & 100 \\
\hline 4 & There is public transportation to the tourist area & - & 100 & - \\
\hline 5 & Have access to private vehicles & - & - & 100 \\
\hline 6 & Have a mode of transportation in the tourist area & - & 3 & 97 \\
\hline
\end{tabular}

The data in Table 5 shows that the villagers of Munduk Temu 100\% agree with accessibility that is still limited, as well as road access that is only sufficient for public transportation $97 \%$ agree. The community also $100 \%$ agrees if there are no sign markers for the existence of a tourist village. There is public transportation to the tourist area, $100 \%$ of the community is doubtful, this also means that there is no public transportation to the tourist area. Access can only be passed by private vehicles, and the community $100 \%$ agrees with this statement. Having a mode of transportation in a tourist area $97 \%$ answered agree and only $3 \%$ answered doubtfully.

Table 6: Community perceptions of Munduk Temu village tourism facilities

\begin{tabular}{|c|c|c|c|c|}
\hline \multirow{2}{*}{\multicolumn{2}{|c|}{$\begin{array}{l}\text { Component } \\
\text { Facility }\end{array}$}} & \multicolumn{3}{|c|}{ Amount (\%) } \\
\hline & & Disagree & Doubt & Agree \\
\hline 1 & Development of tourism facilities is still limited & - & - & 100 \\
\hline 2 & There is already development of tourism infrastructure & - & - & 100 \\
\hline 3 & Use of village public facilities as tourism facilities & - & 3 & 97 \\
\hline 4 & Infrastructure facilities and tourism facilities are adequate & - & 100 & - \\
\hline
\end{tabular}

Public perception of tourism facilities shows that $100 \%$ of the community agrees that the development of tourism facilities is still limited, and 100\% also agrees if tourism development has begun to develop, such as access roads that are being improved (Table 6). Regarding the use of 
village public facilities as tourism facilities, $97 \%$ of the people answered agree, only $3 \%$ were hesitant. For example, the Village Head's Office is used as a place to receive guests who visit, and village calls are used as a place for presentations. Tourism facilities and infrastructure are adequate, the community $100 \%$ answered doubtfully, this relates to point 2 , which states that tourism infrastructure is still under development. Related to the development of tourism facilities that utilize the potential of the community such as gardens and rice fields, $96 \%$ of the public answered agree and $6 \%$ were hesitant. This is meant is a tourist facility located in a community garden, for example in the middle of a coffee plantation.

Table 7: Community perceptions of village institutions and human resources meeting.

\begin{tabular}{|l|l|c|c|c|}
\hline \multicolumn{2}{|l|}{ Component Institutional } & \multicolumn{3}{c|}{ Amount (\%) } \\
\cline { 2 - 5 } & Disagree & Doubt & Agree \\
\hline 2 & Don't have a tourism village management organization & - & - & 100 \\
\hline 3 & Still spontaneously accept tourist visits & 100 & - & - \\
\hline 4 & Still yet available quality development in the field of tourism & - & 100 & - \\
\hline 6 & Can be a model for the development of other tourist villages & - & 3 & 97 \\
\hline
\end{tabular}

Regarding the institutions and human resources in Munduk Temu Village, 100\% of the community agreed that Munduk Temu Village does not yet have a tourism village management organization. The community $100 \%$ disagrees if Munduk Temu Village has spontaneously received tourist visits. The community is $100 \%$ doubtful if there is no mention of developing quality in the field of tourism (Table 7). The community agreed that the village of Munduk Temu did not yet have a tourism village management organization. $97 \%$ of the people agree if they still need assistance from relevant parties and 3\% are hesitant. 100\% of the people do not agree if it is said that the community is independent and able to manage their tourism business independently. 91\% disagreed if Munduk Temu Village could become a model model for the development of other wista villages, $3 \%$ were doubtful and only $6 \%$ agreed. From the above table, the results show that the institutions that manage tourism villages do not yet exist in Munduk Temu Village, and still need assistance.

Table: 8 Community perceptions of community empowerment in the village of Munduk Temu

\begin{tabular}{|l|l|c|c|c|}
\hline \multicolumn{2}{|c|}{ Components of Community Empowerment } & \multicolumn{3}{c|}{ Number (\%) } \\
\cline { 2 - 5 } & Disagree & Doubt & Agree \\
\hline 1 & $\begin{array}{l}\text { The Community is limited to carrying out daily activities to } \\
\text { earn a living }\end{array}$ & - & 91 & 9 \\
\hline 2 & Employment and economic activities have begun to be created & - & 3 & 97 \\
\hline 3 & Public awareness of the potential of tourism began to grow & - & - & 100 \\
\hline 4 & People are already fully aware of the potential for tourism & - & - & 100 \\
\hline 5 & $\begin{array}{l}\text { People directly involved in the management of a tourist } \\
\text { attraction }\end{array}$ & - & - & 100 \\
\hline
\end{tabular}

Public perception of empowerment, 91\% answered hesitation if people merely do daily activities to make a living, but $9 \%$ agree. This is due to the fact that there are also some people who are developing their businesses outside agriculture. $97 \%$ of the community agreed with the start of employment and economic activities for the local community. $100 \%$ of the people agree that public 
awareness of tourism potential has begun to grow. The community is $100 \%$ aware of the tourism potential including its development. 100\% also agree if the community is directly involved in the management of the tourism village (Tabel 8). From the table above we get the results that the community is aware of the tourism potential and will be directly involved in its development and management.

Table 9: Community perceptions of marketing and promotion of village tourism in Munduk Temu

\begin{tabular}{|l|l|c|c|c|}
\hline \multicolumn{2}{|l|}{ Components of Marketing and Promotion } & \multicolumn{3}{c|}{ Amount (\%) } \\
\cline { 2 - 4 } \multicolumn{2}{|l|}{} & Disagree & Doubt & Agree \\
\hline 1 & Not yet / there are still very few tourists visiting & 3 & - & 97 \\
\hline 2 & There is no media promotion about the village tourism etrsebut & - & 100 & - \\
\hline 3 & Tourists have begun to be known and visited & - & 3 & 97 \\
\hline 4 & Already have promotional media & - & 15 & 85 \\
\hline 5 & Already a tourist destination known to tourists & - & 82 & 18 \\
\hline 6 & Need to carry out promotion and marketing independently & - & - & 100 \\
\hline
\end{tabular}

In terms of marketing and promotion, $97 \%$ of the community answered agree if there were not / there were still very few tourists visiting, and 3\% responded doubtfully. Whereas $100 \%$ of the people are doubtful if there is no media promotion about the tourism village. The village of Munduk Temu has begun to be known and visited by tourists, and this is approved by $97 \%$ of the community and only $3 \%$ are hesitant. Regarding point 2) $85 \%$ of the people agreed that Munduk Temu village already had a promotional media, and $15 \%$ were hesitant. Only $18 \%$ agreed that the village of Munduk Temu had become a tourist destination known and visited by tourists, the remaining $88 \%$ were doubtful, and $100 \%$ answered agree that promotion and marketing needs to be done independently (Table 9). From the public perception above, the results obtained that marketing and promotion have not been maximally carried out, even though there are media as a promotional event. And this has an impact on tourist villages that are not yet known and are widely visited.

From the tables above, the results of people's perceptions of the potential of Munduk Temu Village were obtained from various aspects. This perception will be a reference in identifying potential as the basis of tourism area planning. Planning is a process of determining organizational goals and then clearly presenting the strategies, tactics, and operations needed to achieve overall organizational goals (Suandy, 2001). The challenge for tourism planning is to ensure efficient utilization of resources through balanced use of resources, including natural and landscape resources (Romadhon et al, 2013).

\section{Conclusions and Recommendations}

There are a lot of tourism potentials in Munduk Temu Village, including waterfall tours, hot spring baths, clear river water, salak plantations, coffee plantations. Leading potential in the village of Munduk Temu is a coffee plantation managed by the community with an area of about $60 \%$ of the total area of the village of Munduk Temu. Public perception shows that the village of Munduk Temu has the potential to be developed into a tourist village, but tourism accessibility is inadequate, tourism facilities are still limited, institutions are inadequate, but community 
awareness has grown, the community hopes to manage the tourism village independently, and urgently needs promotion media.

\section{Acknowledgements}

Director of the Masters Program in Regional Development Planning and Environmental Management, Mahasaraswati University, Denpasar.

The supervisors, reviewers and examiners of the Thesis MP2WL postgraduate program Mahasaraswati University Denpasar

\section{References}

[1] Central Bureau of Statistics of the Province of Bali in 2010.

[2] Central Bureau of Statistics of Tabanan Regency, 10. Pupuan Sub District in Figures 2019.

[3] Budiarjono and Wardiningsih, S.. 2013 Sustainable Landscape Agrotourism Planning in the Gunung Leutik Area of Bogor, Journal of Architecture Nalars Volume 12 No. 2 July 2013

[4] Erawan, N. 1993. Tourism in relation to the culture and personality of the nation. Ed. TR Sudarta et al. (eds). Culture and civilization. P. 281-99. Denpasar: Upada Sastra.

[5] Suandy, E. 2001. Tax Planning, Issue 1, Jakarta: Salemba Empat

[6] Maruti, KV 2009. Agrotourism: Scope and Opportunities for the Farmers in Maharashtra. Article Report. Dept. Of Economics, YC college. Pachwad Talwai, Dist-Satara, State of Maharashtra.

[7] Nuryanti. 1993. Concepts, Perspectives and Challenges. Paper Part of the International Conference Report on Cultural Tourism. Gajah Mada University Press, Yogyakarta.

[8] Pitana, IG 2002. Bali Local Government Policies and Strategies in Tourism Development. At the National Tourism Seminar, Bali The Last or the Lost Paradise. Sustainable Tourism Development. Denpasar: Udayana University.

[9] Regent's Regulation number 24 year 2018 regarding Action Plan for Tourism Models through the development of integrated agribusiness based on local wisdom and tourism in the Nikosake region.

[10] Regional Regulation 11 of 2012 concerning Tabanan Regional Spatial Planning. Tabanan Regency Government.

[11] Regional Regulation 11 of 2017 concerning Regional Medium-Term Development Plans 20162021

[12] Profile of Villages and Villages of Munduk Temu Village, 2018

[13] Romadhon, A., Ferdinand, Y., Bengen, DG., Adrianto, L. 2013. Planning for Sustainable Development of the Sapeken Island Cluster: An Assessment of the Regional Carrying Capacity for Tourism Development. Planning For Sustainable Development At Sapeken, Tataloka Volume 15 Number 3, August 2013, 218-234.

[14] Decree of the Regent of Tabanan Number:/ HK \& HAM / 2018 concerning the 180/178/02 Location of Integrated Agribusiness Development Based on Local Wisdom and Tourism of the Nikosake Region.

[15] Decree of the Regent of Tabanan Number: 180/314 / 03/2018 concerning Munduk Village meets as a Tourism Village.

[16] Wolfe, K. and G. Bullen. 2011. Considering an Agrotourism Enterprise? The Southern Regional Risk Management Education Center.

*Corresponding author.

E-mail address: widny anaketut@gmail.com 